\title{
Effects of Air Quality and Climate Change on Airway Hyperreactivity in Children (A Multi-Centered Study)
}

\section{Esen Demir ${ }^{1}$, Levent Midyat ${ }^{1 *}$, Demet Can ${ }^{2}$, Ali Kanık ${ }^{3}$, Nevin Uzuner $^{4}$, Figen Gülen ${ }^{1}$, Nejat Aksu ${ }^{3}$, Duygu ÖImez ${ }^{4}$, Suna Asilsoy $^{2}$, Arzu} Babayiğit ${ }^{4}$, Eylem Ulas Saz ${ }^{1}$ and Remziye Tanaç ${ }^{1}$

${ }^{1}$ Ege University Faculty of Medicine, Department of Pediatrics, Division of Pulmonology-Allergy, Izmir, Turkey ${ }^{2}$ Dr. Behçet Uz Hospital of Educational and Research of Children Diseases and Surgery, Pediatric Pulmonology-Allergy, Izmir, Turkey ${ }^{3}$ SSK Tepecik Children's Hospital, Pediatric Pulmonology-Allergy, Izmir, Turkey

${ }^{4}$ Dokuz Eylul University, Faculty of Medicine, Pediatric Pulmonology-Allergy, Izmir, Turkey

\begin{abstract}
The clinical effects of environmental pollution and climate change on respiratory health is a contemporary debate issue. In this study, the sulfur dioxide $\left(\mathrm{SO}_{2}\right)$, particulate matter $\left(\mathrm{PM}_{10}\right)$ levels, and climate conditions in the city of Izmir, have been taken together with the patients with asthma or acute bronchiolitis, who admitted to the children's emergency departments of the four university/education-research hospitals in Izmir. From September 1, 2007 until August 31,2008 , the 22,467 patients who admitted to these centers because of airway hyperreactivity, were of age $3.05 \pm 1.57$ on the average, and the male/female ratio was 1.7 . Among the patients, $79.3 \%$ were having acute bronchiolitis, and $20.7 \%$ an asthma attack. $\mathrm{As} \mathrm{SO}_{2}$ and $\mathrm{PM}_{10}$ levels increase, the daily asthma attacks, patients with acute bronchiolitis, and total of patients with hyperactivity, were observed to increase $(p<0.001)$. In addition, the numbers in the following five days after the increase of air pollution rate, were observed to increase statistically significantly $(p<0.001)$. The number of asthma and acute bronchiolitis patients applying to emergency, was negatively correlated with daily average temperature, but positively correlated with relative humidity, actual air pressure, and sealevel pressure levels $(p<0.001)$. Reflecting on the increase of asthma and acute bronchiolitis in developed societies, there is a necessity of effective reliefs such as effectively monitoring the within-city air quality, taking the industrial centers out of the city, promoting public transportation, and preserving the natural life.
\end{abstract}

Keywords: Air Pollution; Climate Change; Asthma; Acute Bronchiolitis; Children

\section{Introduction}

A correlation between air quality and respiratory diseases has been demonstrated by a large number of studies conducted by different research groups throughout the world, however the association between air pollution and asthma is less obvious. Although there are some contradictory results in the medical literature, an increase has been seen in many studies both in prevalence and in healthcare attendance for asthma, in terms of primary care and hospital emergency settings when air pollution levels are high [1,2]. Most of the studies have shown that excessive mortality and morbidity are associated with increases in air pollution [1,3-7]. This increase in mortality and morbidity has led to increase in studies investigating the different environmental factors that might be associated with the risk of developing asthma and asthma attacks [2].

Children are particularly more vulnerable to the harmful effects of ambient pollution, because they inhale a lot more air per pound of body weight and per lung surface than adults and their developing lungs lack a full defence system to protect them against any harmful effects. The most commonly implicated pollutants are $\mathrm{NO}_{2}$, ozone and particulate matter $\left(\mathrm{PM}_{10}\right.$ and $\left.\mathrm{PM}_{2.5}\right)$. Although experimental studies conducted on animals and humans suggest an effect for sulfur dioxide $\left(\mathrm{SO}_{2}\right)$, ozone $\left(\mathrm{O}_{3}\right)$ and nitrogen dioxide $\left(\mathrm{NO}_{2}\right)$, and more recently, for particulates $[8,9]$ other studies have yielded contradictory results [2,10-13]. During pollution episodes, increased prevalence of respiratory tract diseases, respiratory symptoms, allergen sensitization, worsening of asthma and increased use of anti-asthma medications have been observed in many studies $[1,2,14]$. Similarly, in children exposed to high levels of ambient air pollutants, lung growth has been found to be impaired [14].

While air pollution has been shown to decrease in urban areas of developed countries, high air pollutant concentrations have been recorded in large urban conglomerates of the developing world $[1,15,16]$. The objective of this study was to analyze the short- term association between emergency room admissions for airway hyperreactivity and air pollutants and weather conditions in Izmir, which is the third largest city in Turkey.

\section{Materials and Methods}

In this study, in order to detect the effects of air pollution and meteorological changes on the respiratory health of children, the sulfur dioxide $\left(\mathrm{SO}_{2}\right)$, particulate matter $\left(\mathrm{PM}_{10}\right)$ levels, daily average temperature, relative-humidity, actual air pressure, and sea-level pressure levels in the city of Izmir, have been taken together with the cases of asthma or acute bronchiolitis, who admitted to the children's emergency departments of the four university/education-research hospitals in Izmir, facilities covering an urban catchment area of 3,739,353 inhabitants (Ege University Faculty of Medicine, Dokuz Eylül University Faculty of Medicine, Dr. Behçet Uz Children's Hospital, and Tepecik SSK Children's Hospital). Medical records were evaluated retrospectively by the two pediatric pulmonologists for clinical characteristics, laboratory results, and disease course. The classification of asthma and acute brochiolitis was done according to the international guidelines $[17,18]$. Attack severity was classified as mild, moderate or severe according to the initial symptoms [17]. Pollution data were obtained from Republic of Turkey Ministry of Environment. Continuous samplers were placed at four different points of the city.

*Corresponding author: Levent Midyat, Ege Universitesi Cocuk Sagligi ve Hastaliklari AD, 35100, Bornova, Izmir, Turkey, Tel: 90532405 9763, E-mail: levent.midyat@ege.edu.tr

Received August 08, 2011; Accepted November 06, 2011; Published November 08, 2011

Citation: Demir E, Midyat L, Can D, Kanık A, Uzuner N (2011) Effects of Air Quality and Climate Change on Airway Hyperreactivity in Children (A Multi-Centered Study). J Pulmonar Respirat Med 1:105. doi:10.4172/2161-105X.1000105

Copyright: ( 2011 Demir E, et al. This is an open-access article distributed under the terms of the Creative Commons Attribution License, which permits unrestricted use, distribution, and reproduction in any medium, provided the original author and source are credited. 
Citation: Demir E, Midyat L, Can D, Kanık A, Uzuner N (2011) Effects of Air Quality and Climate Change on Airway Hyperreactivity in Children (A Multi-Centered Study). J Pulmonar Respirat Med 1:105. doi:10.4172/2161-105X.1000105

Page 2 of 6

The measurement data collected at the station computers that are installed are received by the Provincial Directorates and the Central Computer of the Ministry through GSM modems via a special network of the Ministry. Data are expressed as average 24 hours concentrations. According to WHO Standardization criteria, $\mathrm{SO}_{2}$ level over $125 \mu \mathrm{g} / \mathrm{m}^{3}$ and $\mathrm{PM}_{10}$ level over $70 \mu \mathrm{g} / \mathrm{m}^{3}$ were accepted as elevated. Meteorological data were obtained from Forestry State Meteorological Service and Provincial Environmental Directorate of Izmir.

Statistical analysis were performed by using "SPSS (Statistical Package for Social Sciences) 16.0 for Windows" program. $t$-test, oneway ANOVA test and chi-square test were used while evaluating the data. The multiple logistic regression "step-wise" was employed. The variables were age, gender, the pollutants concentrations and the meteorological data. For each pollutant and meteorological change, the effect of the level on the visiting day and on the following five days was analyzed separately. $\mathrm{p}<0.05$ was accepted as statistically significant.

\section{Results}

From September 1,2007 until August 31,2008, 22,467 patients admitted to the four centers because of airway hyperreactivity. Their mean age was $3.05 \pm 1.57$ years ( 16 days- 18 years), and the male/female ratio was 1.7. Among the patients, $79.3 \%(n=17,809)$ were having acute bronchiolitis, and $20.7 \%(\mathrm{n}=4,658)$ an asthma attack; $63.7 \%$ of the patients were having mild attacks, $64.5 \%$ were not having the symptoms of an infection, and $22.2 \%$ were hospitalized because of the hyperreactivity attack. Clinical characteristics of the patients are summarized in (Table 1).

In a total of 86 days, the level of $\mathrm{PM}_{10}$ in air was above the threshold level specified by the World Health Organization. In addition, only in 2 days, the level of $\mathrm{SO}_{2}$ in air was above the threshold level specified by the World Health Organization. There were significant $(\mathrm{p}<0.001)$ differences in $\mathrm{PM}_{10}$ and $\mathrm{SO}_{2}$ levels, among the seasons, especially heightened in winter (Table 2).

The average age of patients admitting to emergency departments because of airway hyperreactivity were decreasing during the winter (Figure 1). As $\mathrm{SO}_{2}$ and $\mathrm{PM}_{10}$ levels increase, the daily asthma attacks, patients with acute bronchiolitis, and total of patients with hyperactivity, were observed to increase $(\mathrm{p}<0.001)$ (Figure 2$)$. Also, the number of patients admitting to the emergency rooms in the following five days after the increase of air pollution rate, were observed to increase statistically significantly $(\mathrm{p}<0.001)$ (Figure 3 and Figure 4$)$. The number of asthma and acute bronchiolitis patients applying to emergency, was negatively correlated with daily average temperature,

\begin{tabular}{|c|c|}
\hline Number of patients $(n)$ & 22,467 \\
\hline Mean age (years) & $3.05 \pm 1.57$ ( 16 days -18 years) \\
\hline Male/female (\%) & $62.8 / 37.2$ \\
\hline Number of patients with acute bronchiolitis (n (\%)) & $17,809(79.3)$ \\
\hline Number of patients with asthma (n (\%)) & $4,658(20.7)$ \\
\hline $\begin{array}{l}\text { Severity of the attack (\%) } \\
\text { Mild } \\
\text { Moderate } \\
\text { Severe }\end{array}$ & $\begin{array}{l}63.7 \\
30.6 \\
5.6\end{array}$ \\
\hline $\begin{array}{l}\text { Findings of infection (\%) } \\
\text { Yes } \\
\text { No }\end{array}$ & $\begin{array}{l}35.5 \\
64.5\end{array}$ \\
\hline $\begin{array}{l}\text { Hospitalization (\%) } \\
\text { Yes } \\
\text { No }\end{array}$ & $\begin{array}{l}22.2 \\
77.8\end{array}$ \\
\hline
\end{tabular}

Table 1: Characteristics of patients admitted to the emergency departments of the four centers.

\begin{tabular}{|l|l|l|l|l|l|}
\hline & Fall & Winter & Spring & Summer & $p$ \\
\hline $\begin{array}{l}\text { Mean } \mathrm{PM}_{10} \text { level }(\mu \mathrm{g} / \\
\left.\mathrm{m}^{3}\right)\end{array}$ & $54.1 \pm 26.8$ & $82.7 \pm 40.9$ & $38.7 \pm 25.0$ & $42.1 \pm 18.9$ & $<0.001$ \\
\hline $\begin{array}{l}\text { Mean } \mathrm{SO}_{2} \text { level }(\mu \mathrm{g} / \\
\left.\mathrm{m}^{3}\right)\end{array}$ & $9.8 \pm 9.3$ & $45.5 \pm 25.0$ & $13.2 \pm 7.3$ & $5.0 \pm 2.7$ & $<0.001$ \\
\hline $\begin{array}{l}\text { Mean daily } \\
\left.\text { temperature ( }{ }^{\circ} \mathrm{C}\right)\end{array}$ & $19.2 \pm 5.1$ & $8.5 \pm 3.0$ & $18.0 \pm 4.0$ & $28.1 \pm 2.3$ & $<0.001$ \\
\hline $\begin{array}{l}\text { Mean daily relative } \\
\text { humidity }(\%)\end{array}$ & $60.9 \pm 12.7$ & $63.9 \pm 10.7$ & $55.5 \pm 11.2$ & $43.5 \pm 9.3$ & $<0.001$ \\
\hline $\begin{array}{l}\text { Mean actual air } \\
\text { pressure }(\mathrm{hPa})\end{array}$ & $1012.0 \pm 6.0$ & $1018.5 \pm 7.3$ & $1009.5 \pm 3.6$ & $1005.8 \pm 2.3$ & $<0.001$ \\
\hline $\begin{array}{l}\text { Mean sea level air } \\
\text { pressure }(\mathrm{hPa})\end{array}$ & $1015.7 \pm 4.6$ & $1022.6 \pm 6.1$ & $1012.4 \pm 5.4$ & $1008.8 \pm 2.6$ & $<0.001$ \\
\hline
\end{tabular}

Table 2: Mean $\mathrm{PM}_{10}$ and $\mathrm{SO}_{2}$ levels and meteorological data during the seasons.

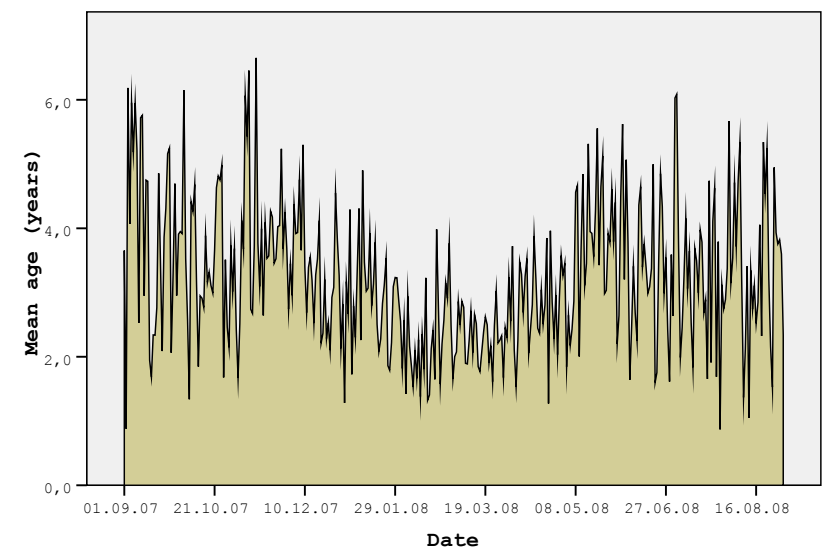

Figure 1: The mean age of patients among the year.

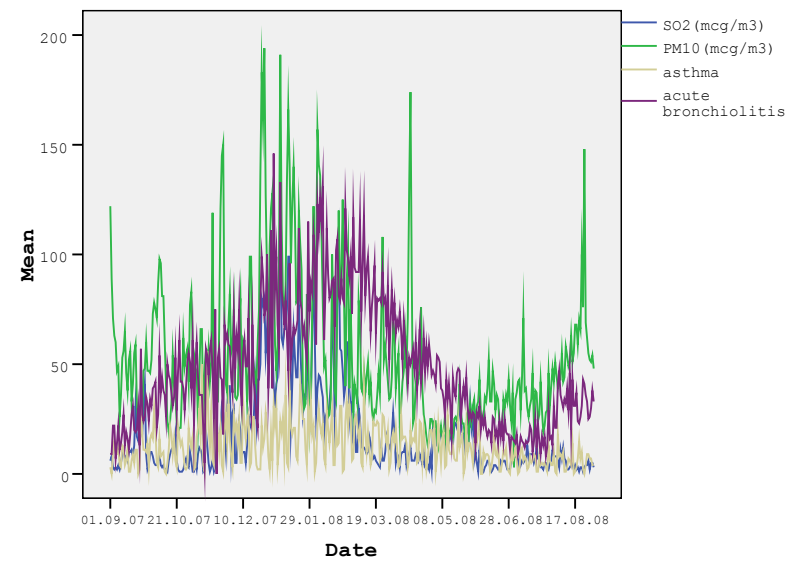

Figure 2: Relationship between air pollution and the number of patients admitting to emergency departments because of asthma and acute bronchiolitis.

but positively correlated with relative humidity, actual air pressure, and sea-level pressure levels $(\mathrm{p}<0.001)$.

\section{Discussion}

Respiratory problems in children are serious public health issues due to their high frequency and negative impact on the quality of life, as well as the human and financial resources that they require. Mainly in developed countries, the prevalence of diseases such as asthma has increased rapidly in recent years, in parallel with changes 
in lifestyle and exposure to environmental factors [19,20]. Asthma and acute bronchiolitis are conditions that likely results from complex interactions between multiple environmental and genetic influences. Numerous risk factors for asthma have been identified including gender, airway hyperreactivity, atopy, allergens, infections, tobacco smoke, obesity, and perinatal factors [21]. Although there is a known correlation between levels of air pollution and lung disease, the association between air pollution and asthma is less clear. As an example, there was a direct relationship between the levels of particulate pollution and reported rates of chronic cough and bronchitis in a study of six cities in the United States. However, there was no association between particulate concentration and asthma, persistent wheeze, or hay fever. Some authors think that, it is possible that asthma is related to specific pollutants, while other respiratory diseases are related to total air pollution $[19,21,22]$.

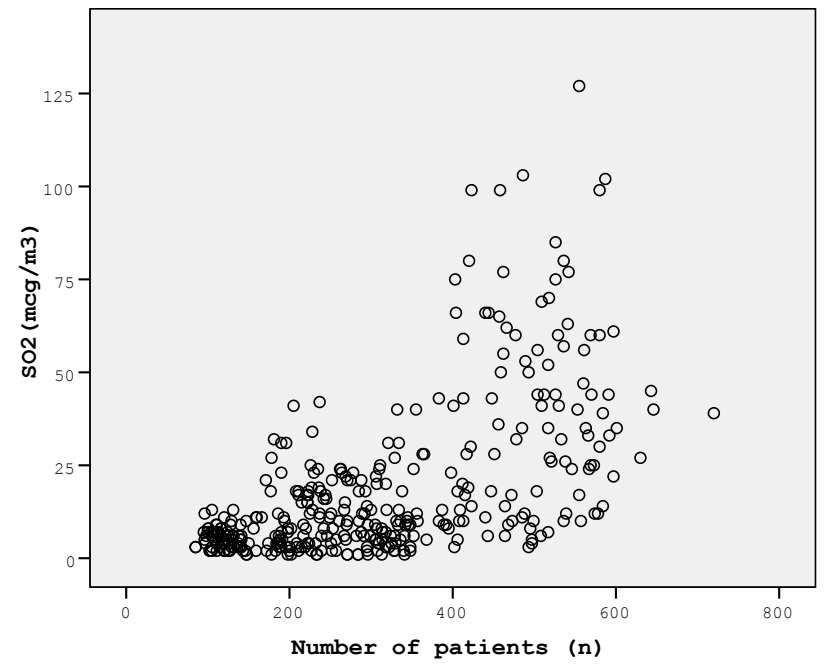

Figure 3: Relationship of $\mathrm{SO}_{2}$ level and the number of patients admitting to the emergency rooms in the following five days.

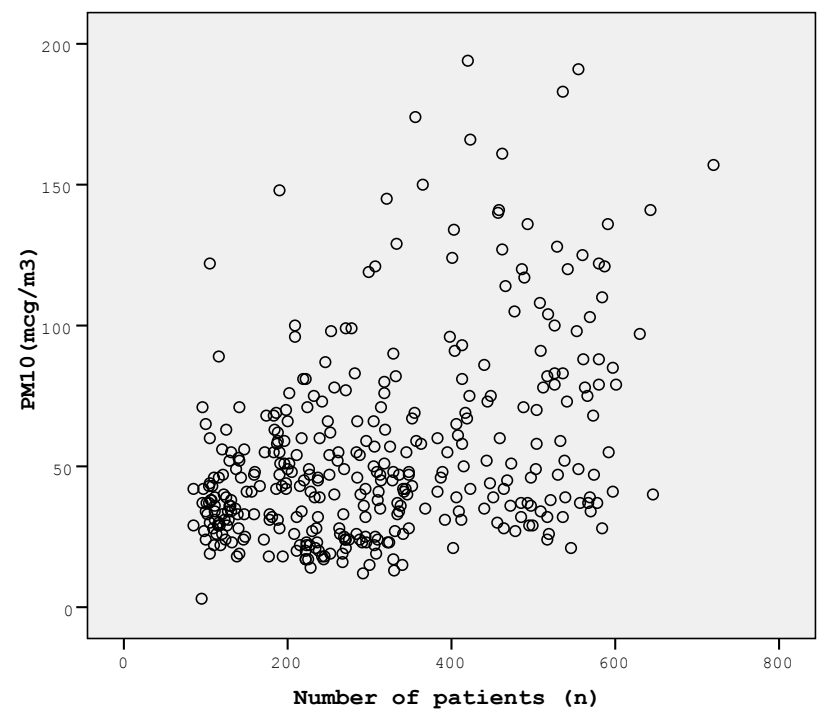

Figure 4: Relationship of $\mathrm{PM}_{10}$ level and the number of patients admitting to the emergency rooms in the following five days.
Humans inhale around 10,000 liters of ambient air daily, which comes in close contact with a lung surface area of over a hundred square meter. From this, on a daily basis, approximately 350 liters of oxygen diffuses across the alveolar capillary basement membrane into the 10,000 liters of blood flowing through the lungs. Therefore, the respiratory tract, comes into close contact with a large volume of ambient air and its components daily [2]. Both in the developed and developing world, rapid urbanization and industrialization with the concomitant increase in vehicular and industrial emissions, have significantly deteriorated the quality of air that we breathe. The harmful substances, especially the fine particles, that we inhale not only get retained in the lungs and cause local injurious effects, but also enter into the systemic circulation through the alveolar capillary basement membrane. Therefore, they have the potential to affect other organs in the body. It has been estimated by the World Health Organization (WHO) that more than 300 million people die every year due to the harmful effects of ambient air. Unfortunately, children seem to be the most vulnerable group to the injurious effects of air pollution $[2,14]$. Air pollution can increase the risk of developing asthma attacks through several different mechanisms including: 1) a direct irritant effect on sensitive airways; 2) a toxic effect on the respiratory epithelium; 3) generating bronchial hyperreactivity, both allergen-specific and nonspecific; or 4) modifying the immune response, by increasing susceptibility to an immunological trigger $[2,8,9]$.

Environmental factors that have been associated with asthma and other respiratory diseases include air pollutants, both inside buildings and outdoors, different allergens like pollens, spores, acarids, and others, as well as climatic factors such as temperature or humidity [19]. In Europe, the impact of environmental pollution on children's health is a very important issue. The ministers of health and environment of the WHO European region signed the European Environment and Children's Health Action Plan in June 2004, in which objectives were set to reduce the mortality and morbidity of diseases related to environmental pollution, in particular, during pregnancy, childhood, and adolescence (The European Environment and Health Action Plan 2004-2010, 2004). A study conducted to provide basic information for the development of this action plan reports that, in Europe, between 1.8 and $6.4 \%$ of deaths in children between 0 and 4 years of age are due to outdoor air pollution and 3.6\% to indoor air pollution [23]. The impact is greater in Eastern European countries, however the authors underline the fact that the effect of environmental hazards on children's health is discernible to some extent in all European countries. At the same time, they point out the lack of adequate information on the levels and conditions of exposure. As a result, the European Union has implemented a strategy to reduce the prevalence of diseases related to environmental factors, giving special attention to the most vulnerable groups, in particular, children [23]. The first cycle of this strategy, corresponding to the period 2004-2010, focus on four effects on health, of which, children's respiratory diseases, asthma, and allergies are the first. For this reason, it is essential to determine the effect of environmental factors on children's health [19].

According to our study, as $\mathrm{SO}_{2}$ and $\mathrm{PM}_{10}$ levels increase, the daily asthma attacks, patients with acute bronchiolitis, and total of patients with hyperactivity, were observed to increase. Also, the number of patients admitting to the emergency rooms in the following five days after the increase of air pollution rate, were observed to increase statistically significantly. Studies in reunified Germany have provided data on two populations exposed to different levels of pollutants [21,24,25]. East Germany had consistently high levels of $\mathrm{SO}_{2}$ and other particulates, whereas West Germany had low levels of sulfur dioxide $\left(\mathrm{SO}_{2}\right)$ but 
slightly higher levels of nitrogen dioxide $\left(\mathrm{NO}_{2}\right)$. The prevalence rates of asthma and atopy were higher in the West German towns, while the rates of bronchitis were higher in the East German towns, suggesting at most a minor effect of air pollution on the prevalence of asthma [24,25]. A large epidemiologic study examined the correlation between asthma symptoms in 990 children in eight North American cities, and the ambient concentrations of five air pollutants [26]. There was a small positive correlation between symptoms and carbon monoxide and $\mathrm{NO}_{2}$ levels, a marginal correlation with $\mathrm{SO}_{2}$ levels, and no relationship with ozone levels or particulate matter. Other studies have examined a possible role of diesel exhaust particles specifically, which are taken up by airway epithelial cells and may stimulate allergic-type immune reactions [21,27-29].

On the other hand, several epidemiological studies have reported associations between residential proximity to busy roads and variety of adverse health outcomes in children, including respiratory symptoms and asthma exacerbations. In a German study that investigated the association between prevalence of wheeze and allergic symptoms with truck traffic density in 13-14-year-old school children, [30]. reported that compared with children who had never been exposed to truck traffic, those children who lived in areas with rare, frequent and constant flow of truck traffic had 29\%,58\% and 57\% increased prevalence of wheeze, respectively [30]. These data suggest that risk of developing asthma is increased in children living in residential areas that have high truck traffic density. In one of the first epidemiological studies in the USA that evaluated relationships between measured trafficrelated air pollutants and respiratory symptoms [31]. found significant associations between traffic-related pollutants and the presence of asthma and bronchitis symptoms in the past 12 months [31]. More recently, [32] reported positive associations between markers of trafficrelated air pollution and respiratory health outcomes, including the onset of asthma, incidence of wheeze, ear-nose-throat infections and serious colds or influenza in a large cohort of children aged 4 years; effects were first noted at the age of 2 years $[14,32,33]$.

In epidemiology, only few studies focused on the role of air pollution as a risk factor for specific respiratory infections, such as acute bronchiolitis. However, experimental data have shown that air pollutants affect lung immune responses and inflammatory reactions and that these effects may underlie the increased risk for respiratory infections [34-38]. A recent study conducted in California, using case-crossover analysis, evaluated air pollutants effect on 19,901 infants between 1995 and 2000 with a hospital discharge record for bronchiolitis in the first year of life [39]. The authors found little support for a link between acute increases in ambient air pollution and infant bronchiolitis, except modestly increased risk for $\mathrm{PM}_{2.5}$ exposure for the most premature infants born at gestational ages between 25 and 29 weeks [34].

Particulates have been one of the pollutants most frequently studied in the assessment of acute health effects, particularly in the case of respiratory diseases [2]. Although particulate sources tend to vary from place to place, the main source of emission is diesel-engine combustion, inasmuch as diesel engines emit a hundred times more particulates than gasoline engines equipped with catalysers [40]. Laboratory studies confirm that the emission of diesel particulates can have effects on the immune system, by acting as an adjuvant that boosts allergic inflammation [41]. Rossi et al. [42] described a positive relationship between total suspended particulates and asthma-related emergencies in the population aged 15-85 years. Castellsagué et al. [43] reported an association at an average lag of 0-3 days between black smoke and emergency room visits in Barcelona among subjects aged $>14$ years.
Recently, studies in Santa Clara, London and Belfast have also observed a significant association between $\mathrm{PM}_{10}$ and asthma-related emergencies $[2,44,11,45]$. In Chile, Ostro et al. [46] found particulate matter $<10$ $\mu \mathrm{m}$ in aerodynamic diameter $\left(\mathrm{PM}_{10}\right)$ to be associated with elevated daily counts of emergency room visits for lower respiratory symptoms among children $<2$ years of age.

Experimental studies have demonstrated that $\mathrm{SO}_{2}$ can induce bronchospasm in nonasthmatics and asthmatics alike. Although the concentrations required provoking these effects in healthy individuals are very high, among asthmatic subjects changes in pulmonary function are brought about at low dose [2,47] In time-series studies, $\mathrm{SO}_{2}$ has been the pollutant for which an association with asthma-related emergencies has least frequently been detected. In Vancouver, Bates et al. observed an association between this pollutant and asthma-related emergency visits among subjects aged $>15$ years [48]. Rossi et al. [42] also observed positive results, as did other recent studies in London and Belfast, where a statistically significant relationship was detected with current- or previous-day pollutant levels $[11,42,45]$. Against this, other studies have failed to demonstrate asthma-related effects $[2,49,50]$.

The association of asthma morbidity with weather conditions has been pointed out as early as the fifth century BC by Hippocrates, which is consistent with the current literature reports of a distinct relationship between the seasonal patterns of asthma attacks and the meteorological observations [51]. However, it is not clear to what extent more specific meteorological variables are implicated in triggering asthma exacerbation. There is evidence that changes in temperature, barometric pressure and relative humidity have some influence on the worsening of asthmatic symptoms [52,53]. In England and Wales, asthma admissions were lowest in winter and peaked in autumn, whereas in Mexico, they were more frequent in the rainy season [53,54]. In Korea, relative humidity was found to be a more important contributing factor than temperature to exercise induced bronchospasm in patients with perennial asthma [52,55]. Contrary to the studies performed in England and Wales, in our study, the number of asthma and acute bronchiolitis patients applying to emergency was negatively correlated with daily average temperature. And, as in study conducted in Korea, the number of asthma and acute bronchiolitis patients applying to emergency was positively correlated with relative humidity.

There may be some misclassification of the diseases in our study, which is a limitation of the research. However, reflecting on the increase of asthma and acute bronchiolitis in developed societies, there is a necessity of effective reliefs such as effectively monitoring the withincity air quality, taking the industrial centers out of the city, promoting public transportation, and preserving the natural life.

\section{References}

1. Farhat SC, Paulo RL, Shimoda TM, Conceição GM, Lin CA, et al. (2005) Effect of air pollution on pediatric respiratory emergency room visits and hospital admissions. Braz J Med Biol Res 38: 227-235.

2. Galán I, Tobías A, Banegas JR, Aránguez E (2003) Short-term effects of ai pollution on daily asthma emergency room admissions. Eur Respir J 22: 802808

3. Firket $J$ (1931) On the causes of accidents in the valley of the Meuse, in the mists of December 1930. Bulletinet Memoirs of the Royal Academy of Medicine of Belgium. 11: 683-741.

4. Logan WPD (1953). Mortality in London fog incident. Lancet 1: 336-338.

5. Fairley D (1990) The relationship of daily mortality to suspended particulates in Santa Clara County, 1980-1986. Environ Health Perspect 89: 159-168.

6. Schwartz J (1991) Particulate air pollution and daily mortality in Detroit. Environ Res 56: 204-213. 
7. Dockery DW, Pope CA, Xu X, Spengler JD, Ware JH, et al. (1993) An association between air pollution and mortality in six US cities. N Engl $\mathrm{J}$ Med 329: 1753-1759

8. Wardlaw AJ (1993) The role of air pollution in asthma. Clin Exp Allergy 23: 8196.

9. Koening JQ (1999) Air pollution and asthma. J Allergy Clin Immunol 104: 717722.

10. Strachan DP (2000) The role of environmental factors in asthma. Br Med Bull 56: 865-882.

11. Atkinson RW, Anderson HR, Strachan DP, Bland JM, Bremner SA, et al (1999). Short-term associations between outdoor air pollution and visits to accident and emergency departments in London for respiratory complaints. Eur Respir J 13: 257-265

12. Atkinson RW, Anderson HR, Sunyer J, Ayres J, Baccini M, et al. (2001) Acute effects of particulate air pollution on respiratory admissions: Results from APHEA 2 Project. Air Pollution and Health: a European Approach. Am J Respir Crit Care Med 164: 1860-1866.

13. Brunekreef B, Holgate ST (2002) Air pollution and health. Lancet $360: 1233$ 1242.

14. Salvi S (2007) Health effects of ambient air pollution in children. Paediatr Respir Rev 8: 275-280

15. Saldiva PH, Lichtenfels AJ, Paiva PS, Barone IA, Martins MA, et al. (1994). Association between air pollution and mortality due to respiratory diseases in children in São Paulo, Brazil: a preliminary report. Environ Res 65: 218-225

16. Saldiva PH, Pope CA 3rd, Schwartz J, Dockery DW, Lichtenfels AJ, et al (1995) Air pollution and mortality in eldery people: a time-series study in Sao Paulo, Brazil. Arch Environ Health 50: 159-163.

17. Global Strategy for Asthma Management and Prevention, Global Initiative for Asthma (GINA) 2010

18. Fitzgerald DA, Kilham HA (2004) Bronchiolitis: assessment and evidencebased medicine Med J Aust 180: 399-404.

19. Fuentes-Leonarte V, Tenías JM, Ballester F (2008) Environmental factors affecting children's respiratory health in the first years of life: a review of the scientific literature. Eur J Pediatr 167: 1103-1109.

20. Gökbel H, Uzun K (1995) Hava kirliliğinin solunum fonksiyonlarına etkileri. Ekoloji 15: 4-5.

21. Augusto A Litonjua, Scott T Weiss. Risk factors for asthma.

22. Dockery DW, Speizer FE, Stram DO, Ware JH, Spengler JD, et al. (1989) Effects of inhalable particles on respiratory health of children. Am Rev Respir Dis 139: $587-594$.

23. Valent F, Little D, Bertollini R, Nemer LE, Barbone F, et al. (2004) Burden of disease attributable to selected environmental factors and injury among children and adolescents in Europe. Lancet 363: 2032-2039.

24. Magnussen H, Jorres R, Nowak D (1993) Effect of air pollution on the prevalence of asthma and allergy: lessons from the German reunification. Thorax 48: 879-881.

25. von Mutius E, Martinez FD, Fritzsch C, Nicolai T, Roell G, et al. (1994) Prevalence of asthma and atopy in two areas of West and East Germany. Am J Respir Crit Care Med 149:358-364.

26. Schildcrout JS, Sheppard L, Lumley T, Slaughter JC, Koenig JQ, et al. (2006) Ambient air pollution and asthma exacerbations in children: an eight-city analysis. Am J Epidemiol 164: 505-517.

27. Bleck B, Tse DB, Jaspers I, Maria A Curotto de Lafaille, Joan Reibman, et al (2006) Diesel exhaust particle-exposed human bronchial epithelial cells induce dendritic cell maturation. J Immunol 176: 7431-7437.

28. Ohtoshi T, Takizawa H, Okazaki H, Kawasaki S, Takeuchi N, et al. (1998) Diesel exhaust particles stimulate human airway epithelial cells to produce cytokines relevant to airway inflammation in vitro. J Allergy Clin Immunol 101: $778-785$

29. Boland S, Baeza-Squiban A, Fournier T, Houcine O, Gendron MC, et al. (1999) Diesel exhaust particles are taken up by human airway epithelial cells in vitro and alter cytokine production. Am J Physiol 276: L604-L613.
30. Behrens T, Taeger D, Maziak W, Duhme H, Rzehak P, et al. (2004) Selfreported traffic density and atopic disease in children. Results of the ISAAC Phase III survey in Muenster, Germany. Pediatr Allergy Immunol 15: 331-339.

31. Kim JJ, Smorodinsky S, Lipsett M, Singer BC, Hodgson AT, et al. (2004) Trafficrelated air pollution near busy roads: the East Bay Children's Respiratory Health Study. Am J Respir Crit Care Med 170: 520-526.

32. Brauer M, Hoek G, Smit HA, de Jongste JC, Gerritsen J, et al. (2007) Ai pollution and development of asthma, allergy and infections in a birth cohort. Eur Respir J 29: 879-888

33. Brauer M, Hoek G, Van Vliet P, Meliefste K, Fischer PH, et al. (2002) Air pollution from traffic and the development of respiratory infections and asthmatic and allergic symptoms in children. Am J Respir Crit Care Med 166: 1092-1098.

34. Ségala C, Poizeau D, Mesbah M, Willems S, Maidenberg M (2008) Winter air pollution and infant bronchiolitis in Paris. Environ Res 106: 96-100.

35. Becker S, Soukup JM (1999) Effect of nitrogen dioxide on respiratory vira infection in airway epithelial cells. Environ Res 81: 159-166.

36. Gilmour MI, Daniels M, McCrillis RC, Winsett D, Selgrade MK, et al. (2001) Air pollutants enhanced respiratory disease in experimental animals. Environ Health Perspect 109: 619-622.

37. Harrod KS, Jaramillo RJ, Rosenberger CL, Wang SZ, Berger JA, et al. (2003) Increased susceptibility to RSV infection by exposure to inhaled diesel engine emissions. Am J Respir Cell Mol Biol 28: 451-463.

38. Lambert AL, Mangum JB, Delorme MP, Everitt JI (2003) Ultrafine carbon black particles enhance respiratory syncytial virus-induced airway reactivity pulmonary inflammation, and chemokine expression. Toxicol Sci 73: 339-348.

39. Karr C, Lumley T, Shepperd K, Davis R, Larson T, et al. (2006) A casecrossover study of wintertime ambient air pollution and infant bronchiolitis. Environ Health Perspect 114: 277-281.

40. Polosa R, Salvi S (1999) Particulate air pollution from motor vehicles: a putative proallergic hazard? Can Respir J 6: 436-441.

41. Casillas AM, Hiura T, Li N, Nel AE (1999) Enhancement of allergic inflammation by diesel exhaust particles: permissive role of reactive oxygen species. Ann Allergy Asthma Immunol 83: 624-629.

42. Rossi OV, Kinnula VL, Tienari J, Huhti E (1993) Association of severe asthma attacks with weather, pollen and air pollutants. Thorax 48: 244-248.

43. Castellsagué J, Sunyer J, Saez M, Anto JM (1995) Short-term association between air pollution and emergency room visits for asthma in Barcelona. Thorax 50: 1051-1056

44. Lipsett M, Hurley S, Ostro B (1997) Air pollution and emergency room visits for asthma in Santa Clara Country, California. Environ Health Perspect 105 216-222.

45. Thompson AJ, Shields MD, Patterson CC, (2001) Acute asthma exacerbations and air pollutants in children living in Belfast, Northern Ireland. Arch Environ Health 56: 234-241.

46. Ostro BD, Eskeland GS, Sanchez JM, Feyzioglu T (1999). Air pollution and health effects: a study of medical visits among children in Santiago, Chile. Environ Health Perspect 107: 69-73.

47. Tunnicliffe WS, Hilton MF, Harrison RM, Ayres JG (2001) The effect of sulphu dioxide exposure on indices of heart rate variability in normal and asthmatic adults. Eur Respir J 17: 604-608.

48. Bates DV, Baker-Anderson M, Sizto R (1990) Asthma attack periodicity: a study of hospital emergency visits in Vancouver. Environ Res 51: 51-70.

49. Romieu I, Meneses F, Sienra-Monge JJ, Huerta J, Ruiz Velasco S, et al. (1995) Effects of urban air pollutants on emergency visits for childhood asthma in Mexico City. Am J Epidemiol 141: 546-553.

50. Cody RP, Weisel CP, Birnbaum G, Lioy PJ (1992) The effect ofozone associated with summertime photochemical smog on the frequency of asthma visits to hospital emergency departments. Environ Res 58: 184-194.

51. Marêtes SAG, Balas CN (1982) Bronchial asthma in the medical literature of Greek antiquity. J Asthma 19: 263-269.

52. Priftis KN, Paliatsos AG, Panagiotopoulou-Gartagani $P$, Tapratzi-Potamianou P, Zachariadi-Xypolita A, et al. (2006) Association of weather conditions with childhood admissions for wheezy bronchitis or asthma in Athens. Respiration 73: 783-790. 
Citation: Demir E, Midyat L, Can D, Kanık A, Uzuner N (2011) Effects of Air Quality and Climate Change on Airway Hyperreactivity in Children (A Multi-Centered Study). J Pulmonar Respirat Med 1:105. doi:10.4172/2161-105X.1000105

53. Khot A, Burn R, Evans N, Lenney W, Storr J, et al. (1988) Biometeorological triggers in childhood asthma. Clin Allergy 18: 351-358.

54. Rosas I, McCartney HA, Payne RW, Calderón C, Lacey J, et al. (1998) Analysis of the relationships between environmental factors (aeroallergens, air pollution, and weather) and asthma emergency admissions to a hospital in Mexico City. Allergy 53: 394-401.

55. Koh YI, Choi IS (2002) Seasonal difference in the occurrence of exerciseinduced bronchospasm in asthmatics: dependence on humidity. Respiration 69: $38-45$. 